doi: 10.14267/cojourn.2019v4n2a6

\title{
The Round Table Movement in Paris and the Rise of a New World Order after WWI
}

\author{
Alessandro D'Onofrio ${ }^{1}$
}

\begin{abstract}
The Paris Peace Conference represented a turning point for the British Empire. Great Britain and its Dominions placed on the side of the Entente all their military might together with the most powerful navy. However, at the end of the war, Britain, in spite of being a victorious country, saw its world hegemony reduced and its control over the widest Empire in the history of the world irremediably affected. On the other side of the Atlantic, the United States turned out to be the real winner of the war and this gave them great leverage in Paris in shaping the new international order. However, the passage from the period of the Pax Britannica, which for almost a century granted stability in Europe, to the Pax Americana, was not so unexpected and painful for the British political establishment as we usually think. Among the British establishment, there was a movement that was able to shape the country's foreign policy for more than twenty years and prepared the ground for the creation of the Anglo-American alliance. This article tries to focus on the circumstances that made possible this transatio imperii and the role played by the Round Table movement in Paris in this respect.
\end{abstract}

Keywords: Paris peace conference, federalism, Round Table movement, British empire, world order, Atlanticism, Anglo-American relationship, Lionel Curtis, Philip Kerr

\section{Introduction: Laying the foundations of a new world order}

The Twentieth Century is in many ways the century that saw the United States rising to become a global power. In this sense, many historians consider the first half of the century as a turning point between the period of Pax Britannica and the inevitable beginning of

\footnotetext{
${ }^{1}$ Alessandro D'Onofrio is international relations manager and member of the EU-V4 office of the Antall József Knowledge Centre. His primary research interests are Italian politics, Italian organized crime, federalism in the UK and the Anglo-American special relationship.
} 
doi: 10.14267/cojourn.2019v4n2a6

Pax Americana (Louis, 2006). This definition is only partially correct, since the rise of the United States was not so unexpected and uncontrollable as it could appear, but was the result of a process of rapprochement between the British and American élites which started at the end of the First World War. Despite the revolutionary and dramatic way in which the "American Century" - to use Henry Luce's well-known phrase - began, it is more appropriate to consider the rise of the United States to the status of superpower more in terms of continuity than a departure from the previous balance of forces in world politics (Luce, 1941: 61-65). From this perspective, the US intervention in the First World War and the American participation at the Paris Peace Conference set off the handover of world hegemony between the two most powerful Anglo-Saxon nations or, as Zimmern aptly emphasized, it formalized the rise of the Third British Empire (Zimmern, 1926: 120).

Following Zimmern's classification, the First British Empire began to take shape in the 17th century as an empire of the old type, such as those of Spain, Portugal, France and the other states of continental Europe. This empire reached its apex with the conquest of the North American territories, and it officially ceased to exist in July 1776, with the American Declaration of Independence. The Second Empire represented a more complex institution based on the British control of sea routes and on the supremacy of the Royal Navy. Its incredible development was stimulated by the rapid and immense growth of international commerce. The conclusion of this second British imperial experience occurred with the Great War and its tragic outcome. Finally, the Third British Empire was an empire of a new type, based on a very specific form of cooperation. The British Commonwealth of Nations was a structure where the right of self-government was recognized with a view to the former Dominions - at least those considered developed enough to manage their own institutions - and where every part of the Empire obtained an equal representation at the post-War Conference. In fact, the war showed how British control over their empire became a complicated matter. The growing threats coming from the new world powers - namely, Germany and Japan - needed an increased investment in naval rearmament that Britain could no longer bear alone. It was therefore vital to bring the United States on board, to renounce its isolation and take an active part in the maintenance of the balance of power in favour of the Anglo-Saxon world. However, at the end of the Great War, in the United States there still did not exist the subjective conditions for their association with the direction of world politics (Kendle, 1989: 1-8). 
doi: 10.14267/cojourn.2019v4n2a6

\section{From the rise of the Round Table movement to "Pax Anglo-Americana"}

Although the Paris Peace Conference is often represented as a meeting between David Lloyd George, Woodrow Wilson, Georges Clemenceau and - not exactly form a position of equality - Italy's Prime Minister Vittorio Emanuele Orlando, a number of attendants in the French capital city were themselves historians, academics, or belonged to influential political circles. Among them, a group of delegates from the British Empire belonged to a very influential movement, which, behind the scenes, was able to influence Britain's foreign policy for almost twenty years, setting the conditions for the establishment of a new world order. The members of the Round Table movement - this was the name of the group - who went to Paris were high-ranking officials of the British political establishment, such as Alfred Milner (Colonial Minister and Chairman of the Commission appointed to draft the mandates), Philip Kerr (then Lord Lothian, private secretary of Lloyd George), Lionel Curtis (adviser to the British Delegation), Robert Cecil (Chairman of the Supreme Economic Council); the Australian John Latham, Frederic Eggleston, and Robert Garran; and George Beer from the U.S. However, it was Lionel Curtis' and Philip Kerr's role in Paris that was decisive in laying the foundations of the new Anglo-American system of power (Kendle, 1965: 8-16).

In order to better understand the Round Table's ideas and how its members could successfully influence the British Prime Minister and the work of the Peace Conference during one of the most dramatic periods of British history - along with the Battle of Britain and Brexit - it is important to explain from where the movement originated. The nucleus of the main group - the membership of the Round Table movement spanned all of the self-governing Dominions - was based on Milner's "Kindergarten" which played an important role in the creation of the South African Union. The Kindergarten was a group of young Oxford graduates who were recruited to help Milner resettle the Transvaal after the 2nd Anglo-Boer War. In South Africa, according to Milner, the British should have imposed the union of the four colonies which in turn would have led to the consolidation of the Empire. Once the South African Union was established, the attention should have focused on the creation of an organic union of the Empire in which all of the self-governing colonies could have played their part in deciding about - and taking responsibility for - the great questions of defence and foreign policy (Headlam, 1931: 287). Together with his religious faith in the Empire, Milner was influenced by the dominant philosophies of the time, which included social Darwinism, an unquestionable belief in the certainty of the superiority of the English-speaking peoples, a sense of 
doi: 10.14267/cojourn.2019v4n2a6

responsibility towards non-Europeans, and finally the idea of an Imperial mission (Worsfold, 1913: 219).

In 1905, when Lord Selborne succeeded Lord Milner as High Commissioner for Southern Africa and governor of the Transvaal and Orange River colonies, the Kindergarten, and, especially, Lionel Curtis - the most active among Milner's disciples - became increasingly preoccupied with the imperial implications of South African Union and began discussing the formation of an organisation to achieve a wider integration of the Empire (Bosco, 2017: 1-3). After achieving the creation of the South African Union, in 1909 Lionel Curtis presented his idea to the others to found the Round Table, a movement whose main aim was the creation of an organic union of all of the British colonies. As Bosco describes,

"the Round Table developed and propagated a political ideology which would have promoted and accompanied the transition from a British leadership of the Empire into an equal partnership among its component parts. (...) The invention of the principle of representation, and of federal government, they thought, were contributions which the Anglo-Saxon political tradition had offered to the development of the principle of self-government invented and experimented with in Athens, making thus possible its application to the national, and then to the supranational levels. (...) If it were not possible to achieve that goal within the English-speaking peoples, who were the most advanced in the art of responsible and democratic government, they believed that nobody else could have succeeded. The British Empire in fact appeared to the Round Tablers as the most congenial organization of States to start with, in order to create and consolidate a federal nucleus set for enlargement" (Bosco, 2017: 4).

The members of the Round Table thus became involved in the Irish question, which was the most heated topic of British domestic politics in the years preceding the First World War. According to Curtis, Ireland was not a solely domestic matter, but a question which involved the Dominions and the existence of the Empire. According to the London group, creating a federation of the British Isles would have represented the first step towards the separation of domestic from imperial affairs. Freeing the Parliament of all the local matters it was called to legislate upon - by means of the creation of local parliaments for every constituent part of the United Kingdom - would have granted policy-makers more time to discuss imperial issues. In order to reach their aim, the members of the Round Table attempted to exert influence through the press and by contacting the most influent 
doi: 10.14267/cojourn.2019v4n2a6

representatives of the main political forces of the time, including the likes of Winston Churchill - converted to the federalist cause by Curtis - as well as Lloyd George, Austen Chamberlain, Edward Carson (leader of the Ulster Unionists), Bonar Law, Arthur Balfour and others (Kendle, 1989: 172-175).

Other than bringing the Round Table to the fore of the British political debate, the Irish question caused the first open rupture with Milner. The father figure of the group was strongly opposed to home rule for Ireland and was aware of the fact that selfgovernment was too big a concession to Irish nationalists, who would not ultimately accept anything short of complete independence from Britain. As a staunch unionist, Milner was concerned that an independent Ireland would start a domino effect all across the empire, with the inevitable end of British economic, financial, political and military world supremacy (Bosco, 2017: 240-247). In order to stop the introduction of home rule, Milner decided to put all his power and influence into embracing the cause of Protestant Ulster and granting them every kind of support, included military (Lewis, 2006: 22-41). In 1912, the introduction of a third Home Rule bill opened up a deep political crisis around the issue of Ireland and the outbreak of civil war was expected at any time. In fact, following the creation of the Ulster Volunteers, the signing of the British Covenant supported also by Leo Amery, another Round Table member - and the episodes of Curragh and Larne, the member of the Round Table decided to devise a federal plan for the United Kingdom with a temporary exclusion of Ulster from the Irish unit. However, this kind of solution was hardly a compromise since it would have never been accepted by the Irish and would have left Ulster in a limbo, leaving the conflict between the two parts of the island unresolved. At the end, only the outbreak of WWI prevented the outbreak of a civil conflict in Ireland (Kendle, 1989: 153-155).

Despite the failure of their federalist plan, the involvement of the Round Table in the Irish question represented a beneficial experience for the London members. They had been forced to deal with a dimension of the wider imperial question. However, following this first experience, Kerr's view of the distinctiveness of the two issue areas - Ireland and the Empire - prevailed, and the group decided to focus their attention exclusively on what they distinctly looked at as the imperial dimension (Bosco, 2017:245-247).

By 1914, the Round Table movement was present in all the Dominions and the local groups were crucial in keeping alive the debate on defence, foreign policy and the development of Imperial relations. During the war years, Lionel Curtis' activities went uninterrupted and his publication - The Project of a Commonwealth - became from mid- 
doi: 10.14267/cojourn.2019v4n2a6

1915 the movement's Bible as such. From its strong advocacy of the creation of an Imperial federation based on the American model, with federal leadership being in charge of foreign and defence policies, retaining the power to raise revenues directly, it became apparent that the movement reached its maturity, and it was time to enter into the political arena. However, Curtis' federalist plans were not shared by all the members of the London group and some of them believed that such a measure would have alienated the support of those advocating a simple co-operative settlement (Curtis, 1916: 1-35).

Unexpectedly, Milner openly supported Curtis' federal scheme presented in front of the Empire Parliamentary Association on 28 July 1916. However, not a single Dominion Member present agreed with them (Hall, 1920: 166). Few months later, at the spring session of the 1917 Imperial War Conference, Resolution IX was passed, promoting a "readjustment" of imperial relations at the end of the war, "based on the full recognition of the Dominions as autonomous nations of an Imperial Commonwealth," and the preservation of "all existing powers of self-government and complete control of domestic affairs." The Dominions should have obtained "an adequate voice in foreign policy and in foreign relations," and "effective arrangements for continuous consultation in all important matters of common Imperial concern" should have been agreed upon. The Resolution was a hard blow for Curtis, since it ruled out forever federalism as a solution to the crisis of the Empire (Donnelly, 1960: 170-182).

When the conflict was over, the Round Table was well aware that the war effort was the Empire's swansong, and for this reason they recognized that a new approach in foreign policy was needed. It was at that time that the movement progressively shifted its focus from imperial to international questions (Bosco, 2017: 295-296).

The merit of the Round Table was to have recognized before others that the conflict started the process of transferring the centre of the international relations from the Channel to the Atlantic. To make this passage swift and painless, the movement focused all its energies on the creation of a close relationship with the United States (Hancock, 1962: vol. 1., 429-432).

Lloyd George's rise at 10 Downing Street, in which Lord Milner and the London group played a crucial role, represented the big occasion for the Round Table to push its ideas at the centre-stage of British politics. Following the Lloyd George leadership, Milner - supported by the Cecil family - was able to concentrate a vast amount of power in his hands and rapidly became the most powerful and influential force within the executive. From his position, Milner managed to appoint many members of the Round 
doi: 10.14267/cojourn.2019v4n2a6

Table in key posts within the new administration. The most remarkable was the appointment of Philip Kerr at Lloyd George's Private Secretariat from where he was able to push directly on the Prime Minister the Round Table's agenda. From this moment on, having reached the centre of power, the movement began to exercise a political and cultural leadership which, for the next twenty years, had a fundamental impact on the evolution of British institutions and the British role in international affairs (Bosco, 2017: 360-363).

Following his appointment, Kerr started to build a very close relationship with the Prime Minister and ultimately served as Lloyd George's chief adviser and even as his intermediary in foreign affairs. In this position of unprecedented influence, Kerr dedicated himself to the realization of the Round Table's wider objective of a new world order. In the war years, Kerr devoted much of his effort to two fundamental concerns: the definition of post-War aims and the strengthening of British relations with the United States. Kerr believed the war had not been a test of strength of the British Empire against the Central Powers but a war whose ultimate aim should have been "the democratization of Europe." In Kerr's view, British support for European democratic and national movements would weaken the Central European Powers, and converge towards the British idea of a democratic peace. Kerr believed that the post-war system should have been built on the newly established Supreme War Council which would also have provided the basis for the newly established post-war Anglo-American co-operation (Kerr, September 1915: 772-796). At the same time, Wilson's plans for a league of nations entered into the forefront of political debate. The American president's innovative approach to international relations found large support in Great Britain, but Kerr, in spite of his long advocacy for a system of mutual defence, believed that "international machinery or treaties were not able to guarantee, by themselves, international peace, which could be achieved only through the creation of a federation, not a league of nations" (Bosco, 2017: 366). He thus showed Lloyd George his concerns regarding the binding obligations and ties generated by the League. In 1918 and 1919, Kerr, together with Maurice Hankey, the long-time secretary to the British cabinet, became a central figure in the protracted - ultimately unsuccessful - British efforts to modify the League of Nations from the blueprint envisaged by Wilson, attempting to create a body with less extensive powers, particularly in terms of compulsory sanctions against transgressor nations (Roberts, 2004: 97-217). Kerr suggested to convert the Treaty of London "into a permanent international agreement", to be extended also to non-European powers, and to 
doi: 10.14267/cojourn.2019v4n2a6

have every country commit "to respect the peace settlement and to maintain the Reparations necessary [to] enforce respect for international law on others, and to meet together from time to time in order to consider by full and frank discussions between responsible ministers, international problems as they arise." The future of the world depended, according to Kerr, on that "great association of free peoples," which constituted "all enlightened nations," coming together "not to dominate the world or seek aggrandizement for themselves, but to protect the weak among nations, and to ensure that right and not the will of strongest shall be the governing principle in international affairs." Only the British Empire, in Kerr's view, incarnated this ideal, and it was worthy of a “thousand Leagues of Nations" as such (Bosco, 2017: 367).

From this time onward, Kerr's deepest political conviction remained apparently unchanged: his belief in a deeper Anglo-American understanding as the foundation for a new international order. During the war, his already numerous American contacts expanded significantly. Cooperation between Washington and London would draw the United States, according to Kerr, into a wider peace-keeping role that Britain could no longer perform on its own. Kerr's ideas had a great influence on Lloyd George and Kerr's presence in Paris represented a turning point in his public career (Saucier, 2008: 90-96).

In Paris, Kerr was very optimistic regarding the geo-political settlement of Europe to be decided at the Conference, and he believed that the Allied victory would allow a redrawing of frontiers which would forever eliminate "nationalist jealousies." However, Kerr feared that the most serious problems would arise on the subject of the treatment of the colonies and of their "politically backward peoples." Members of the Round Table believed that only direct intervention by the European powers would protect politically backward populations from the corrupting influences caused by the impact of Western civilisation, while encouraging their progress towards self-government. Regarding the United States' role at the Conference, Kerr wrote a letter to Curtis in October 1918 where he described his concerns. Kerr thought that the United States and Britain would continue to cultivate their partnership in the post-war years despite the fact that the Americans, unlike the British, still had "a childlike faith in the virtues of democracy and laissez faire," and a different "attitude towards the problem of world government," tending to believe that the assumption of international responsibilities was "iniquitous imperialism" (Butler, 1960: 69).

According to Kerr, these differences were very harmful because they could have adversely affected Anglo-American relations during the Peace Conference and also 
doi: 10.14267/cojourn.2019v4n2a6

thereafter. Kerr thus concentrated all his efforts until his death in December 1940, to persuade the United States to take responsibility for the world order (Saucier, 2008: 97). Most of Kerr's ideas were taken up by Curtis in his article Windows of Freedom, published in December 1918, which was a passionate appeal for Anglo-American cooperation to guarantee the adequate functioning of the League, lest the Americans return to their pre-war policy of "isolation" (Bosco, 2017: 385-386). According to Curtis, unless the United States would have shared with the British Empire "the burden of world government," the world would have experienced "the greatest danger which can threaten mankind." Thanks to this article, Curtis received an invitation from Cecil to attend the work of the Peace Conference, and provided the underlying inspiration for the creation in late May 1919 - on the initiative of Curtis himself - of the Institute of International Affairs (Bosco, 2017: 387-388).

The Paris Peace Conference had brought together officials and experts who were playing a major role in the process of the formation of foreign policy in their own countries and for this reason seemed vital to establish among them an institutional link to continue this work (McKercher, 1991: 1). The creation of the Institute followed a meeting between the British and American delegates - mostly involving the members of the Inquiry set up in September 1917 by Wilson's closest advisor Colonel Edward M. House - at the Hotel Majestic on 30 May 1919, where they agreed to create an organisation "which would act as a telephone exchange between few hundred men in each country who administer foreign affairs and create public opinion on the subject" (Bosco, 2017: 440).

The Institute represented a strategic change of the objective of the Round Table, since the reform of the Empire was no longer a likely outcome and the centre of gravity of world power had already shifted from the Channel to the Atlantic. Kerr and Curtis felt that they had to prepare the transition from an Anglo-French to an Anglo-American diarchy, and the Institute of International Affairs - later known as Chatham House - was the perfect tool to achieve this goal. According to Quigley, "the influence of Chatham House appears in its true perspective, not as the influence of an autonomous body but as merely one of the many instruments in the arsenal of another power," namely the Round Table movement. The role of this movement in the fields of education, administration, politics, newspapers, and periodicals was incredible since "a small number of men" obtained an "almost complete control over the publication of the documents relating to their actions," to exercise "such influence over the avenues of information that creates 
doi: 10.14267/cojourn.2019v4n2a6

public opinion," and "to monopolize so completely the writing and the teaching of the history of their own period" (Quigley, 1981: 197).

As a matter of fact, the role played by Chatham House and the Council of Foreign Relations - its sister office in New York - in preparing the ground for the transatio imperii is not comparable to any other institutions (King-Hall, 1937: 1-17). These institutes - defined in today's parlance as think tanks - were the first to deal with the then-established science of international relations.

\section{Conclusion}

The formation of Anglo-American "institutionalized" cooperation played a crucial role during WWII, when the United States decided to intervene in the interest of the Englishspeaking world in the fight against Nazi Germany. Bringing the Americans on board to share the British burdens, and establishing in this way an Anglo-American world hegemony, was the masterpiece of the members of the Round Table. In spite of the failure in creating a closer union of the Empire, those who took part in the movement widened and strengthened the concept of Pax Britannica, turning it into Pax Anglo-Americana, which was to last for much of the 20th century (Mansergh, 1982: vol. 1, 207-214). As Bosco correctly emphasized, "the policy of Atlantic Alliance was not therefore the result of just a temporary convergence of the reasons of state of Great Britain and the United States during the First World War," but "the accomplishment of a political project pursued by two organizations specially created at Paris in May 1919 and active since then on both side of the Atlantic" (Bosco, 2017: 265-466).

\section{References}

Bosco, Andrea. The Round Table Movement and the Fall of the 'Second' British Empire (Cambridge: Cambridge Scholars Publishing, 2017).

Butler, James R. M. Lord Lothian (Philip Kerr), 1882-1940 (London: Macmillan, 1960). Curtis, Lionel. The Problem of Commonwealth (London: 1916).

Donnelly, M. S. "J. W. Dafoe and Lionel Curtis-Two Concepts of the Commonwealth," Political Studies, 8, (1960): 170-82.

Hall, Duncan H. The British Commonwealth of Nations (London: 1920).

Hancock, W. Keith. Smuts. The Sanguine Years (Cambridge: 1962), vol. 1.

Headlam, Cecil. The Milner Papers. South Africa 1899-1905 (London: Cassel, 1931). 
doi: 10.14267/cojourn.2019v4n2a6

Kendle, John. The Round Table Movement the Imperial Union (Toronto: University of Toronto Press, 1975).

Kendle, John. Ireland and the Federal Solution: The Debate Over the United Kingdom Constitution, 1870-1921 (Kingston and Montréal: McGill-Queen's University Press, 1989).

Kerr, Philip. "The End of the War", The Round Table, September 1915, No. 20: 772-796

King-Hall, Stephen. Chatham House: A Brief Account of the Origins, Purposes and Methods of the Royal Institute of International Affairs (London: Oxford University Press, 1937).

Lewis, Geoffrey. Carson: The Man Who Divided Ireland (London: Bloomsbury Academic, 2006).

Louis, William Roger. 'The Pax Americana: Sir Keith Hancock, The British Empire, and American Expansion,' in Ends of British Imperialism: The Scramble for Empire, Suez and Decolonization: Collected Essays (London: I.B. Tauris, 2006).

Luce, Henry. "The American Century", Life (17 February, 1941), 61-5. Available: $<$ https://books.google.hu/books?id=I0kEAAAAMBAJ\&printsec=frontcover\&re dir_esc $=\mathrm{y} \# \mathrm{v}=$ onepage $\& \mathrm{q}=$ century $\& \mathrm{f}=$ false $>$

Mansergh, Nicholas. The Commonwealth Experience (London: Palgrave Macmillan, 1982), vol. 1.

McKercher, Brian J. C. “"The Deep and Latent Distrust': The British Official Mind and the United States, 1919-1929," in Anglo-American Relations in the 1920s: The Struggle for Supremacy, Brian J.C. McKercher ed. (London: 1991).

Quigley, Carroll. The Anglo-American Establishment (San Pedro, CA: GSG and Associates, 1981).

Roberts, Priscilla. "Lord Lothian and the Atlantic World", The Historian, Vol. 66, No. 1 (Spring 2004): 97-127.

Saucier, Craig E. Mr. Kerr Goes to Washington: Lord Lothian and the Genesis of the Anglo-American Alliance, 1939-1940 (Louisiana State University, 2008).

Worsfold, Basil W. The Reconstruction of the New Colonies under Lord Milner (London: Kegan Paul, Trench, Trübner and Company, Ltd., 1913), vol. 2, 219.

Zimmern, Alfred. The Third British Empire (London: Humphrey Milford, 1926). 